\title{
コルベ電解反応に及ぼす酢酸塩, プロピオン酸塩水溶液の濃度異常性*
}

\author{
関根 \\ 功** \\ Effect of the Concentration of Acetate or Propionate on the \\ Abnormal Phenomena in the Kolbe Reaction*
}

Isao SEKINE**

To investigate the state of fatty acids adsorbed on the anode interface, the surface tension-potential curves of platinum, gold, and palladium anodes were measured by use of the du Nouiy tensiometer in aqueous solutions of acetate or propionate.

The value of surface tension in both carboxylate solutions became generally lower than that obtained in the blank solution with increasing concentration of the salts at any electrode used. In the case of platinum, especially, surface tension was found to decrease almost regularly, and to depend on the concentration.

The surface excess concentration at platinum in both carboxylate solutions showed a fairly evident positive maximum at around $1 M$ for any potential. It was considered that the steep decrease of surface excess concentration following these maxima was evidence of the occurrence of such abnormal phenomena as minimization of current efficiency. This seems to explain the fact that, in the electrolysis of aqueous solutions of acetate methane, especially, was formed at low current densities at concentration as low as $1 M$.

The surface excess concentration at gold and palladium was almost always a large negative value at around $1 M$ concentration, suggesting that the adsorption and discharge of hydroxyl ion are the predominant reactions.

\section{1 緒 言 (Introduction)}

酢酸塩やプロピオン酸塩の水溶液中での陽極反応の機 構を調ベるために, 前報》までは白金, 金, パラジウ ム，二酸化鉛および黒鉛電極についての陽極举動を界面 の微分容量一電位ならびに電位一電流の関係を求めて検討 してきた.

これら両脂肪酸塩水溶液での電解反応では，白金電極 のとき特に濃度が $1 M$ 付近になると, 定電位電解にお けるコルベ反応の電流効率に極小が現われること2), ま た定電流法による陽極界面挙動の検討の結果では界面微 分容量の低下 ${ }^{3}$, 電位一電流のターフェル線の卑な電位へ の移行 ${ }^{33}$,4) などいくつかの異常な現象が観測されてい る.

本報では，これらの現象に及ぽす濃度の役割を明らか にするため表面張力計を用いて電極界面での吸着状燞を 調べた，陽極として白金，金抢よびパラジウムを選んだ のは,これらの陽極材料は脂肪酸イオンの吸着状態が異

* 昭和 47 年 3 月笔気化学協会第 39 回大会（東京）にて発表

** 東京理科大学理工学部 (野田市山崎東龟山) Faculty of Science and Technology, Science University of Tokyo (Noda, Chiba)
なっていること，才なわち酢酸塩水溶液中でのコルベ反 忍が白金では起り ${ }^{2)}$, 金拉よびパラジウムではまったく 起らないことらが知られているので，この点を考虑し， これらを比較することも含めて検討するために上記 3 種 の電極を用いることとした.この結果，特に白金での表 面過剩量 $\Gamma$ は, 両脂肪酸塩についてどの電位でも $1 M$ 付近にかなり顕著な正の極大が認められた．この極大に 伴う $\Gamma$ の急激な低下と，電流効率の極小などをはじめ こする上述の異常な現象との関連について種々の検討を 試みた。

\section{2 実験 (Experimental)}

\section{1 装置および方法}

表面張力と電位の関係は表面張力計により求めた．測 定の回路を Fig. 1 に示す. 用いた表面張力計は中村理 科工業のデュヌイ表面張力試験器である.この試験器の リングを試料陽極として用いた．対極は白金板 $(20 \times 30$ $\times 0.5 \mathrm{~mm}$ ) である. 測定セルは容量 $200 \mathrm{~m} l$ 硬質ビーカ 一の上部を切り、シャーレ状にしたものを用いた．試料 


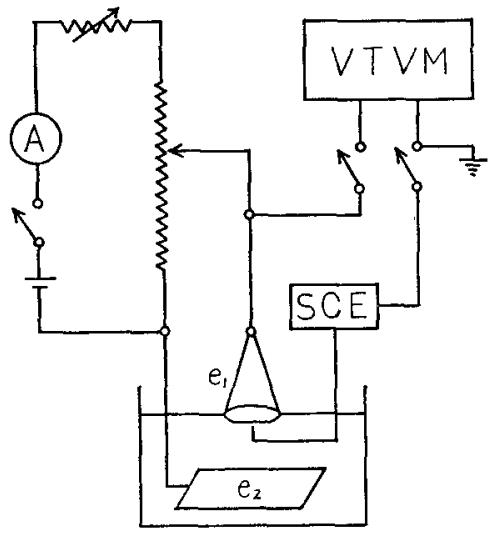

Fig. 1 Circuit diagram

$e_{1}:$ Test electrode, $\quad \mathrm{A}:$ Ammeter $e_{2}$ : Counter electrode, VTVM : Voltmeter S.C.E. : Saturated calomel electrode

陽極の電位は飽和力ロメル電極（S.C.E.) 基隻にし て，0.5 V より貴な電位方向に $0.1 \mathrm{~V}$ 間隔で印加し，そ れぞれの電位での表面張力を 3 回ずつ測定して，それを 平均した值を曲線にして示した，このときの測定精度は $\pm 2 \%$ 以内であった. 測定江 $21 \sim 25^{\circ} \mathrm{C}$ の宣温で行っ た。な掞温度が 3〜4 度異なっても，実測值への影響は ほとんどないことを予储実験により確認した。

\section{2 試料極および試料液}

試料陽極法白金，金およびパラジウムのリングであ る. 白金は直径 $0.29 \mathrm{~mm}$, リングの内径 $12.90 \mathrm{~mm}$, また金とパラジウムは直径 $0.41 \mathrm{~mm}$, リングの内径 $12.45 \mathrm{~mm}$ である. 電極面の前处理として，白金はアル コールて脱脂後, 水, $1 N$ 硝酸, 水, $1 N$ 塩酸, 水の順 に洗浄した。金はアルコールで脱脂後，水， $1 N$ 塩酸， 水の順で，またパラジウムはアルコールで脱脂した後， 水で洗浄した。

試料液は, ブランク液に $0.5 \mathrm{M}$ 硫酸カリウムを用 い，これに酢酸塩またはプロピオン酸塩を加えて使用し た.こ扎ら両脂肪酸塩の濃度は $0.5 M, 1 M, 2 M$ 拈よ び $5 M$ である．用いた塩はすべてカリウム塩である. 試薬はすべて市販特級品をそのまま用い，試料液の調製 には 3 回蒸留の電導度水用いた。

\section{3 結果および考察 (Results and Discussion)}

\section{1 白金陽極について}

Fig. 2 注酢酸㸃水溶液中での 白金陽極についての表 面張力-電位曲線を示す．表面張力は一般に高濃度にな るほどブランク液のものより低くなり，浱度依存性が認 められた. 酢酸塩の濃度に対してこの表面張力を電流効 率22と同時に示したのが Fig. 3 である.表面張力と電

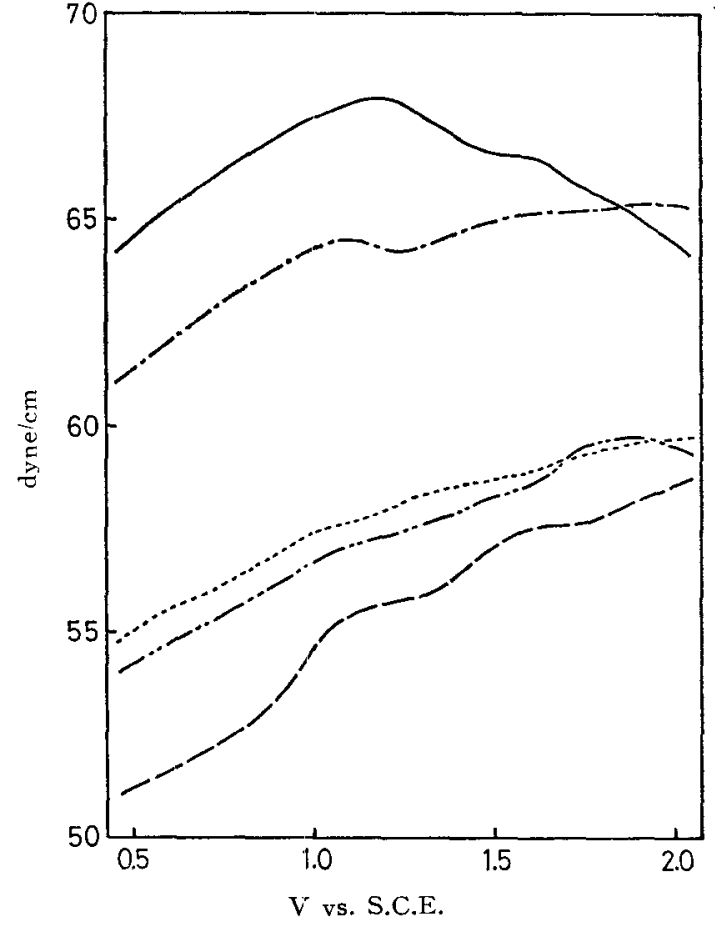

Fig. 2 Surface tension vs. potential curves on platinum in sulfate solutions containing acetate

Blank, -.-: $0.5 \mathrm{M},-\cdots-: 1 \mathrm{M}$

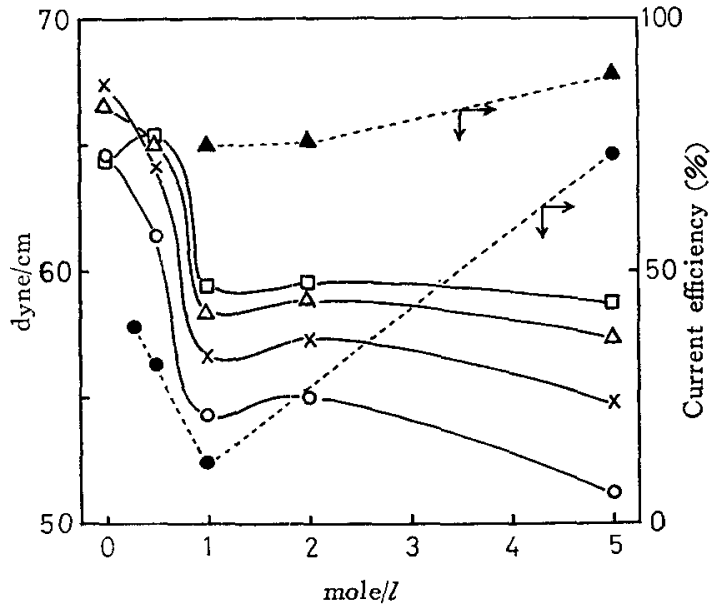

Fig. 3 Effects of acetate concentration on surface tension and current efficiency at platinum

$O: 0.5 \mathrm{~V}, \times: 1.0 \mathrm{~V}, \triangle: 1.5 \mathrm{~V}$
$\square: 2.0 \mathrm{~V}, \quad: 2.0 \mathrm{~V}, \triangle: 2.1 \mathrm{~V}$

流效率はともに酶酸塩濃度が 0.5 から $1.0 \mathrm{M}$ 亿高くな るとき急滅していることが明らかである.

Fig. 4 は, Fig. 2 に基づいてギブスの式により電位 


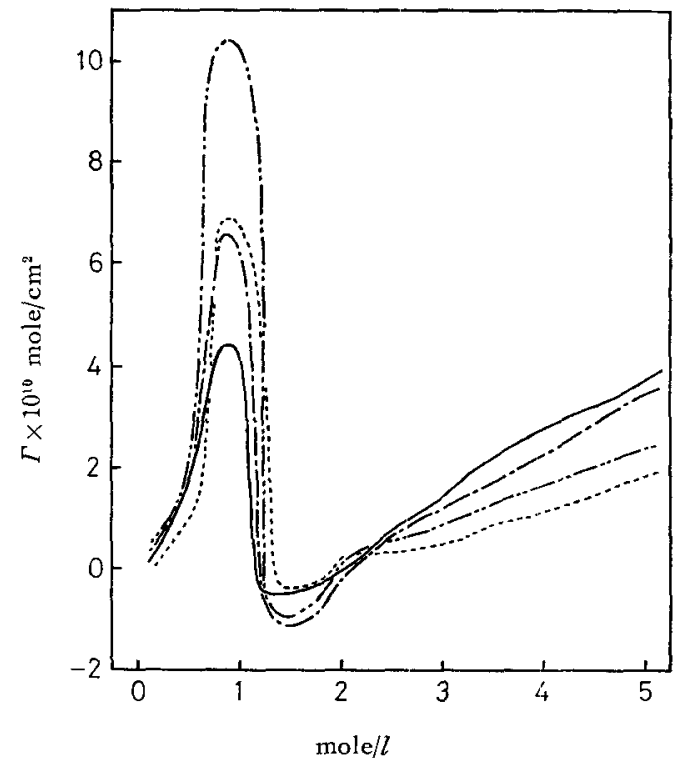

Fig. 4 Surface excess concentration vs, acetate concentration curves on platinum

$$
\begin{aligned}
& -: 0.5 \mathrm{~V},---: 0.8 \mathrm{~V} \\
& \cdots-1.0 \mathrm{~V}, \ldots-1.5 \mathrm{~V}
\end{aligned}
$$

を一定にして表面過剩濃度 $\Gamma$ を求め,この值を酶酸塩 の濃度に対して示したものである。ギブスの昅着式が成 立するのは，(i) 吸着は平衡に達していること，(ii）希 薄溶液であることなどの条件が擜たされていることであ る.もしこれらの条件が満たされていないるきはこの吸 着式は箱密に適用することはできない。このような観点 からすると，本実験での条件は，たとえば濃度は希薄な 溶液でないのでギブスの吸着式を適用するのは無理であ ると考えられる。しかし求めた $\Gamma$ 法熱力学的な意味は なくなるかも知れないが，吸着が電極により，また濃黀 によってどのように変わるかというような一つの知見を 得るためにはこの試みも有效であると誟えた. Fig. 4 ではどの電位でも $1 M$ 近傍で $\Gamma$ は顕著な極大を示し， この極大値は貴な電位になるほど大きく，1.0 V のとき $10.4 \times 10^{-10} \mathrm{~mole} / \mathrm{cm}^{2}$ を示して最高值が得られた。この ように貴な電位になるほど $\Gamma$ の極大値汃大きくなる傾 向は，0.1M 酢酸塩で Kazarinov らりによって示され た $\Gamma$ 曲線でも $1.5 \mathrm{~V}$ より貴な電位になるほど $\Gamma$ は急 増しているのとにている。なお $2 M$ 以上では，高濃度 になるほど $\Gamma$ は増加し，この増加は貴な電位になるほ どゆるやかになっているのが見られた。

Fig. 5 はプロピオン酸塩水浴液中での表面張力-電位 曲線を示寸この図においても酢酸塩のとさと同㥞に高 濃度になるほど表面張力は低下した。

Fig. 6 は, Fig. 5 から求めた $\Gamma$ 曲線を示す。この 曲線でも酢酸塩のときと同様に $\Gamma$ は $1 M$ 近傍で顕著

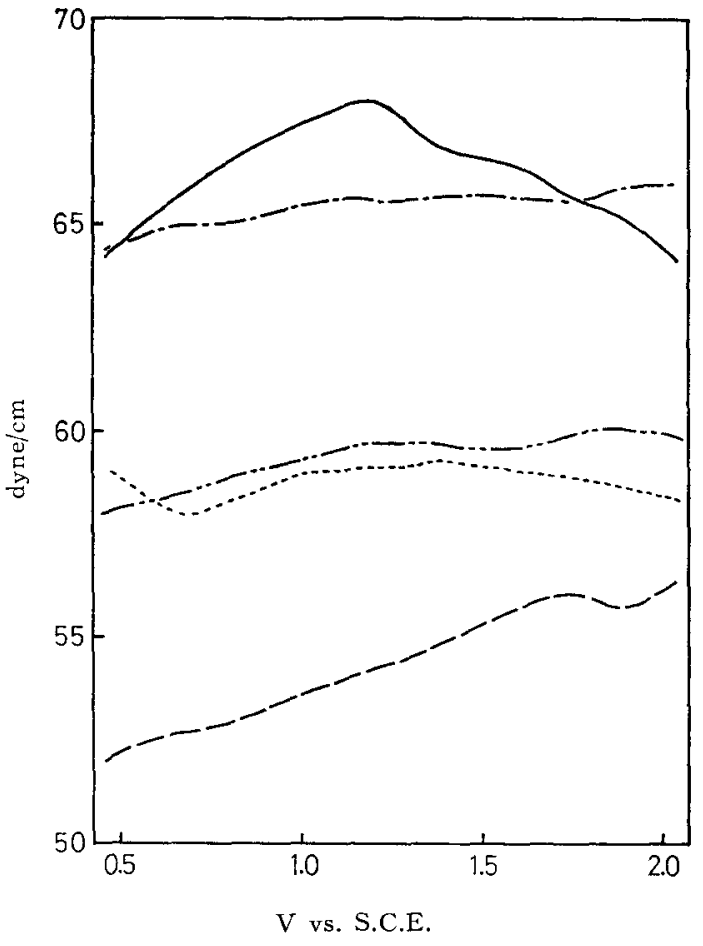

Fig. 5 Surface tension vs. potential curves on platinum in sulfate solutions containing propionate

- : Blank, - - $: 0.5 M,-\cdots-: 1 M$
$---: 2 M$,

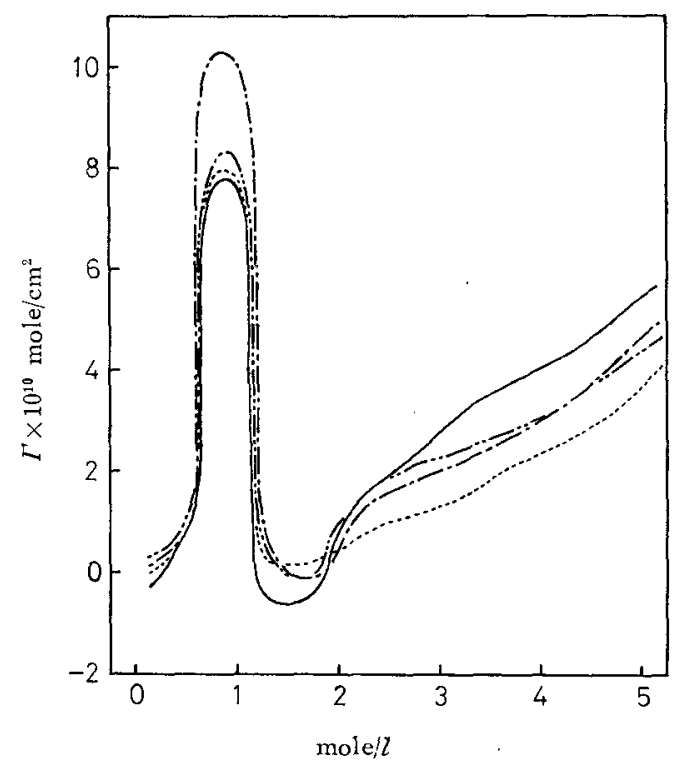

Fig. 6 Surface excess concentration vs, propionate concentration curves on platinum

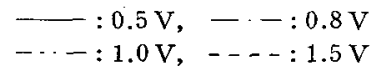


な極大を示し，この極大值は $0.8 \mathrm{~V} の と き ~ 10.3 × 10^{-10}$ $\mathrm{mole} / \mathrm{cm}^{2}$ で最高值を示している. また $2 M$ 以上での $\Gamma$ の増加の仕方は酢酸塩のときとまったく同様であっ た.

以上のように白金では，両脂肪酸塩で $1 M$ 付近に $\Gamma$ のかなり顕著な極大が現われ，これについで $\Gamma$ の急激 な減少が認められたのである.しかも $1 M$ から $2 M$ の 濃度範囲では両脂肪酸塩とも $\Gamma$ は極小を示し, ゼロあ るいは負の值が得られた.このような $\Gamma$ の極大, 極小 はおそらく脂肪酸イオンの電極界面での吸着状態の変化 に基づくのであろう. 才なわち，白金表面一のこ扎ら脂 肪酸イオンの吸着量は濃度に対し規則的に増加していな W(1 $M$ 付近での異常な) 事夷は吸着現象が異なること に基づくものと考えられる.

この証拠として酶酸塩の電解 ${ }^{2}$ で住，2.00 2.10 V の とき低い電流密度 $\left(0.5 \sim 1.0 \mathrm{~A} / \mathrm{dm}^{2}\right)$ においてコル゙二 量化生成物のエタンはもらろん生成するが，このほか特 にメタンが生成されていることがあげられる。このメ夕 ン生成反応は

$$
\begin{aligned}
& \mathrm{CH}_{3} \mathrm{COO}^{-} \longrightarrow \mathrm{CH}_{3} \mathrm{COO} \cdot+e \\
& \mathrm{CH}_{3} \mathrm{COO} \longrightarrow \mathrm{CH}_{3}+\mathrm{CO}_{2}
\end{aligned}
$$$$
\mathrm{CH}_{3} \cdot+\mathrm{CH}_{3} \mathrm{COOH} \longrightarrow \mathrm{CH}_{4}+\cdot \mathrm{CH}_{2} \mathrm{COOH}
$$

で示され，このような低電流密度では $\mathrm{CH}_{3}$ ・の濃度，す なわち $\mathrm{CH}_{3}$ ・の吸着量が $1 M$ 付近ではかなり低いこと を意味していると考えられる。

また, プロピオン酸塩の電解》でも, 電位は早になる ほど，そして電流密度は低くなるほどコル心゙二量化生成 物の $n$-ブタンは少くなり，他の炭化水素（エチレン， エタン)，プロピオン酸エチルエステル，酸化生成物( エ チルアルコール，アセトアルデヒド)などが生成されて いるので，プロピオン酸塩においても酢酸塩のときし同 様に $1 M$ 付近では $\mathrm{C}_{2} \mathrm{H}_{5}$ ・の濃度はかなり低いここ意 味していると想定される.

このように酢酸塩では $\mathrm{CH}_{3} ・$ ，プロピオン酸塩で汶 $\mathrm{C}_{2} \mathrm{H}_{5}$ ・ の吸着量が $1 M$ 付近で特に少くなるのは, おも らく共存している水酸イオンによる影響と思われる.

Table 1 は両脂肪酸塩の濃度に関し, 白金陽極でのい
ろいろな結果を比較して示したものである。表からも明 らかなように, $\Gamma$ の特徴的な変化は, 電流効率の極小23 (Fig. 3), 微分容量の低下 ${ }^{3}$, ターフェル線の早な電位

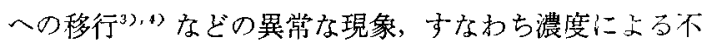
規則な変化が起ったことの証执としてあげられた。これ は前述のごとく酢酸塩の電解2に扔いて，1Mの上うな 低濃度で，しかも低電流密度では特にメタンが生成する が，高電流密度ではそれがまったく生成しないこ上孛説 明し得た.

な怙 $2 M$ 以上では，高濃度になるほど $\Gamma$ は増加する ことが雨脂肪酸塩で共通して見られた。このことな网脂 肪酸塩でコルバ二量化生成物が得られているこ之上関連 性があるものと考えられる。

\section{2 金およびパラジウム陽極について}

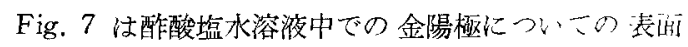
張力-電位曲線を示寸. この図では, 測定電位籍囲 $0.5 M$ の曲線は $1 M$ の曲線より下になるのがはっ吕り 見られ，白金の上きのよらな表面張力の濃度依存性仗認 められなかった。

Fig. 8 は酢酸塩水溶液中でのパラジウム陽極につい ての表面張電位曲線を示寸。この図では $0.5 M の$ 曲 線が $2 M$ の曲線の下になるなど表面張打漂度上上も に規則的に変化することは見られなかった。

Fig. 9 は金とパラジウムでの表面張力と酢酸塩濃度 との関係を示寸，両電極とも特に $0.5 M$ 利近で表而張 力の極小が見られた。

このような表面張力の結果から $\Gamma$ 汪どのようになる か，Fig. 10 は金についての Fig. 7 から求放た $\Gamma$ 曲線 の一例を示す， $\Gamma$ はどり電位でも $1 M$ 近信で白金の上 きとは逆に極小が現むれ，負の值を示した。また $2 M$ 以上では， $\Gamma$ は正の值を示しているが，2.0 Vの場含左 除くと高濃度になるほど $\Gamma$ 法減少した。

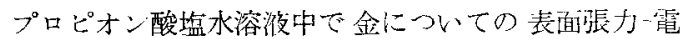
位曲線は，ブランク液の曲線が奍な電位側て $0.5 M$ や $1 M の$ 曲線より低い值を示した。このと圭の $\Gamma$ 曲線 は，酢酸塧で見られたような極小は認められなかった

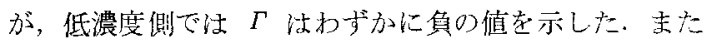

\begin{tabular}{|c|c|c|c|c|c|c|}
\hline \multirow{2}{*}{ Electrolyte } & \multirow{2}{*}{ Results } & \multicolumn{5}{|c|}{ Concentration $(M)$} \\
\hline & & 0.5 & 1 & 1.5 & 2 & $\overline{5}$ \\
\hline \multirow{3}{*}{ Acetate } & Current efficiency $^{2)}(\%)$ at $2.0 \mathrm{~V}$ & 31 & 12 & 20 & 27 & 73 \\
\hline & Potential ${ }^{4}(\mathrm{~V})$ at $1 \mathrm{~mA} / \mathrm{cm}^{2}$ & 1.45 & 1.39 & - & 1.40 & 1.50 \\
\hline & $\begin{array}{l}\text { Surface excess concentration } \Gamma\left(\text { mole } / \mathrm{cm}^{2}\right) \times 10^{10} \\
\text { at } 1.0 \mathrm{~V}\end{array}$ & 2.0 & 10.3 & -1.0 & 0.1 & 2.4 \\
\hline \multirow{3}{*}{ Propionate } & Diff erential capacity ${ }^{3)}\left(\mu F / \mathrm{cm}^{2}\right)$ at $2 \mathrm{~mA} / \mathrm{cm}^{2}$ & 23 & 20 & - & 51 & 91 \\
\hline & Potential $\left.{ }^{8}\right)(V)$ at $2 \mathrm{~mA} / \mathrm{cm}^{2}$ & 1.04 & $1.0 \mathrm{C}$ & - & 1.02 & 1.31 \\
\hline & $\begin{array}{l}\text { Surface excess concentration } \Gamma\left(\text { mole } / \mathrm{cm}^{2}\right) \times 10^{10} \\
\text { at } 0.8 \mathrm{~V}\end{array}$ & 0.8 & 10.1 & 0.0 & 0.5 & 4.6 \\
\hline
\end{tabular}

Table 1 Comparison of some results of platinum anode on the concentration 


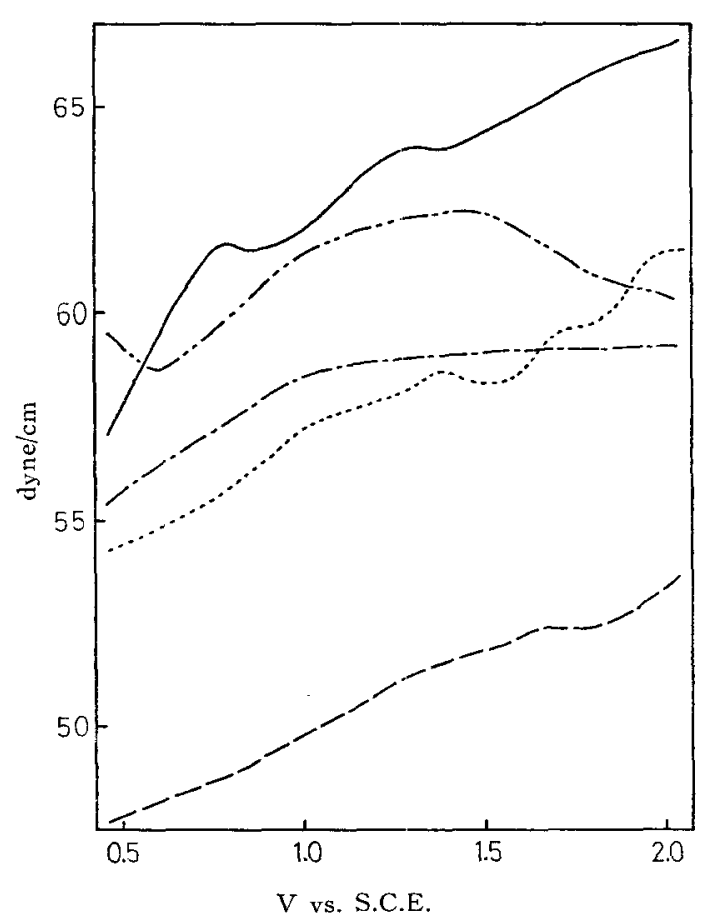

Fig. 7 Surface tension vs, potential curves on gold in sulfate solutions containing acetate

$$
\begin{aligned}
& \text { : Blank, - - : } 0.5 M, \quad-\cdots-1 M \\
& ---: 2 M, \quad--: 5 M
\end{aligned}
$$

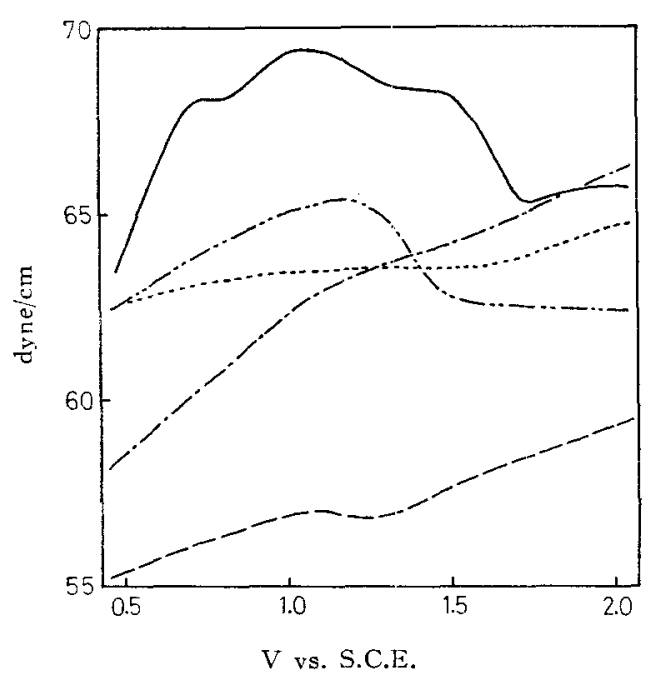

Fig. 8 Surface tension vs, potential curves on palladium in sulfate solutions containing acetate

$$
\begin{aligned}
& \cdots-: \text { Blank, } \cdots-10.5 M,-\cdots: 1 M \\
& \cdots-: 2 M, \quad \cdots-5 M
\end{aligned}
$$

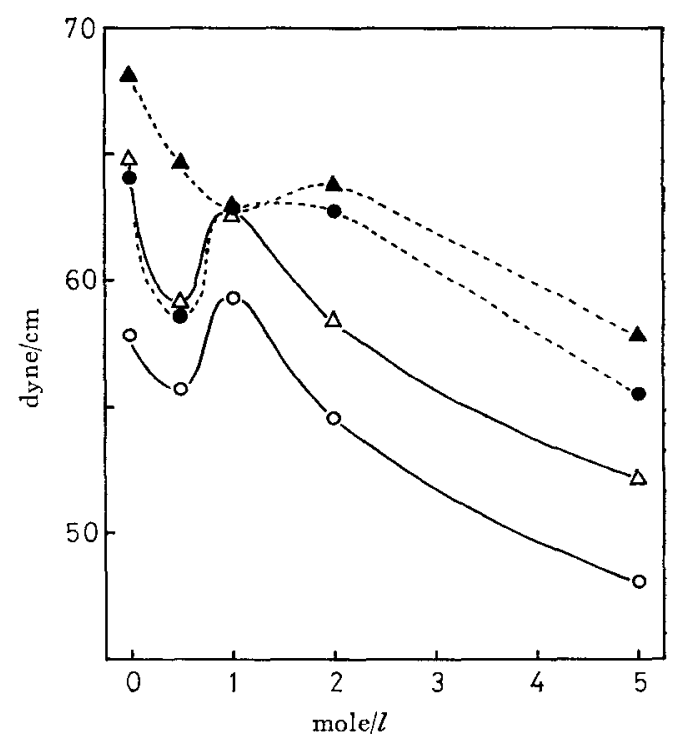

Fig. 9 Surface tension vs, acetate concentration curves on gold and palladium

$\mathrm{O}: \mathrm{Au}, 0.5 \mathrm{~V}, \triangle: \mathrm{Au}, 1.5 \mathrm{~V}$

- : Pd, $0.5 \mathrm{~V}, \quad \triangle: \mathrm{Pd}, 1.5 \mathrm{~V}$

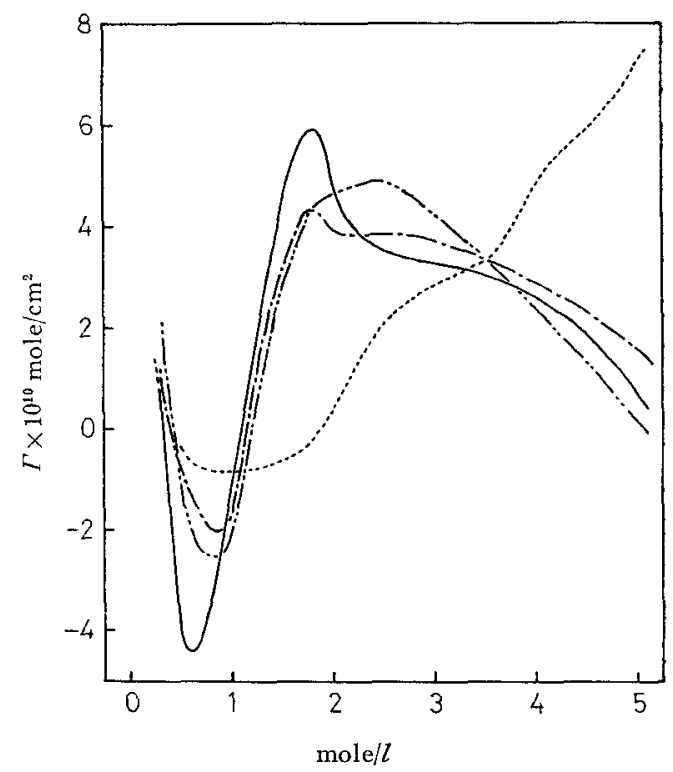

Fig. 10 Surface excess concentration vs. acetate concentration curves on gold

$$
\begin{array}{r}
-0.5 \mathrm{~V},-\cdot-: 1.0 \mathrm{~V} \\
--: 1.5 \mathrm{~V},---: 2.0 \mathrm{~V}
\end{array}
$$

高濃度側での正の值は，酢酸塩のときと同様にやはり高 濃度になるほど減少した。

このように, 酶酸塩水溶液ではコルべ応がまったく 起らない電極として知られている金電極では, 両脂肪酸 塩で $\Gamma$ は低濃度側で負の值を示し, 極大をへたのち高 
濃度になるほど正の值は減少する傾向が見られた．この ような $\Gamma$ の減少傾向は，すでに前報るで述べた酶酸イ才 ンの金電極についての表面被覆率 $\theta$ が $0.5 M$ 以上では ゼロ以下になったこととよく対応している，したがっ て,このことは脂肪酸イオンよりは水酸イオンの吸着放 電がほとんどの反応であることを示唆しているものと考 えられる。

つぎにパラジウムについては, 前述のFig. 8 加ら求め た $\Gamma$ 曲線は, $1.5 \mathrm{~V}$ より貴な電位になるほど白金のと きと同じように $1 M$ 近傍で極大を示した.しかし， $1.5 \mathrm{~V}$ 上り卑な電位になるほど $\Gamma$ は，金で得られた曲 線ににて $1 M$ 近傍で極小を示し，負の值が得られた。 また $2 M$ より高濃度側では， $\Gamma$ はすべて高濃度になる ほど増加するのみで，この傾向は白金の型と一致して いた.

なおパラジウムについてのプロピオン酸塩水溶液中で の表面張力-電位曲線は, $0.5 M$ の曲線が $1 M$ の下に なるなど, 表面張力は濃度により規則的な変化をしてい なかった.このときの $\Gamma$ 曲線は $0.6 M$ 近傍で極小を 示し, 負の值が得られた. しかもこの極小での負の值は 卑な電位になるほど增加していた。 つぎに $1.1 M$ より 滈濃度側では， $\Gamma$ は正の值となり，この曲線の型は金に ついて得られた曲線と類似していた。

以上の上うにパラジウムでは, 両脂肪酸塩で $\Gamma$ は, 低濃度側で卑な電位になるほど金で得られたのと同様に 貧の大きな值が得られた.このことは，パラジウム電極 界面に打ける脂肪酸イオンの吸着放電について, 前述の 金について行ったのと同様に説明できるむのと考えられ る.しかしながら，貴な電位側では，むしろ白金のとき と同じような説明を行ってよいと思われる.この事実は 実際の電解に扔いても，パラジウムが水溶液中で注主上 して金とよくにた挙動を示し，ただきわめて貴な電位側 では白金とにた挙動を示すことと対虑すると考えること
ができる。

$$
4 \text { 総 括 (Summary) }
$$

酢酸塩, プロピオン酸塩の水溶液中で白金，金抢よび パラジウム陽極についての表面張力-電位曲線を表面張 力計によって測定し, 電極界面での吸着状態を検討した ところつぎの結果を得た。

（1）表面張力は, 両脂肪酸塩に関し使用した電極で は高濃度になるほど一船にブランク液の值より低くな り，特に白金ではほぼ規則的に低くなって濃度依存性が 認められた。

（2）表面過剩量 $\Gamma$ は，白金では雨脂肪酸塭につ、 てどの電位でも $1 M$ 付近にかなり䫓著な正の極大を示 し,これについで $\Gamma$ の急激な低下は, 電流効率の極小 などの異常な現象が起ったことの証拠としてあげられ た.こ北酶酸塩の電解仙いて $1 M$ のような低濃度 で特にメタンが生成していることを説明し得た。

(3) 金やパラジウムでの $\Gamma$ は, $1 M$ 付近でほ上ん どが負の大きな值が得られた.このことは，肪脂酸イオ ンよりは水酸イオンの吸着放電がほとんどの反応である ことを示唆しているものと考えられた。

本研究を行うにあたりご指導を賜わった東京工業大学関根 太郎教授ならびに実験に協力された小能文雄君に深く感謝い たします。

$$
\begin{aligned}
& \text { (Received Aug. 30, 1972) } \\
& \text { 文. 献 }
\end{aligned}
$$

1) 関根 功, 本誌 41, 376 (1973).

2) K. Sugino, T. Sekine, N. Sato, Electrochem. Tech. 1, 112 (1963).

3）関根 功, 本誌 41，339 (1973).

4) 関根 功, 関根太郎, ibid. 37, 131 (1969).

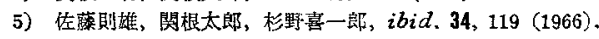

6) V.E. Kazarinov, G.P. Girina, Elektrokhimiya 3, 167 (1967).

7）千明恭一, 閶根太郎, 本誌 38, 130 (1970).

8) 関根 功, ibid. 41, 412 (1973). 